\title{
Efficacy of pyraclostrobin on the production and chemical composition of forage and silage of wheat (Triticum aestivum cv. BRS Umbu) and oats (Avena strigosa cv. Embrapa 139) preceded by successive cuts in the hard dough grain stage
}

\author{
Eficácia da piraclostrobina sobre a produção e bromatologia da \\ forragem e da silagem de trigo (Triticum aestivum cv. BRS Umbu) \\ e de aveia (Avena strigosa cv. Embrapa 139) precedidos de cortes \\ sucessivos na fase de grão farináceo
}

\author{
Bruno José Venancio ${ }^{1 *}$; Mikael Neumann²; Marlon Richard Hílario da Silva ${ }^{3}$; \\ Giovanna Bobato Pontarolo ${ }^{4}$, Leslei Caroline Santos ${ }^{5}$; Luísa da Costa ${ }^{4}$; Leandro \\ Alvarenga Santos ${ }^{6}$; Jhonatan Spliethoff ${ }^{7}$
}

\begin{abstract}
The objective of the experiment was to evaluate the productivity, nutritional value and degradability of forage and silage of wheat (Triticum aestivum cv. BRS Umbu) and black oats (Avena strigosa cv. Embrapa 139), preceded by successive cuts, harvested at the hard dough stage, subjected or not to treatment with pyraclostrobin fungicide. Plants were harvested manually with a height of $0.08 \mathrm{~m}$ from the ground surface, at the hard dough stage, after two cuts at the vegetative stage; two applications of pyraclostrobin, $0.6 \mathrm{~L} \mathrm{ha}^{-1}$ were made, before the first and the second cut. Pyraclostobin decreased the dry matter losses from $21.1 \%$ of the control system to $7.7 \%$ for the system with pyraclostrobin, reduced the neutral detergent fiber from $70.05 \%$ to $66.73 \%$, decreased detergent fiber acid from $43.37 \%$ to $39.96 \%$, decreased lignin from $14.37 \%$ to $10.13 \%$ and increased the relative value of the food from $75.27 \%$ to $82.72 \%$, all in the forage, which resulted in changes in silage, with a decrease in neutral detergent fiber from $64.00 \%$ to $58.46 \%$, acid detergent fiber from $38.76 \%$ to $35.87 \%$, lignin from $10.11 \%$ to $6.78 \%$ and an increase in the relative value of the food from 85.87 to 97.26 . In the evaluation of the forages, wheat presented the best productivity, with $10,068 \mathrm{~kg} \mathrm{ha}^{-1} \mathrm{vs} .8,238 \mathrm{~kg} \mathrm{ha}^{-1}$ black oats, lower neutral detergent fiber $(60.32 \%$ vs. $76.46 \%)$, lower acid detergent fiber ( $34.49 \%$ vs. $48.84 \%)$ and higher relative value of the food ( 96.04 vs. 61.95), these data were from the forage, which were reflected in the resulting silage. It is recommended to use pyraclostrobin as it reduces losses during fermentation, changes fiber composition and improves the degradability of the food. Among the forages, the wheat was more
\end{abstract}

1 Médico Veterinário, M.e em Ciências Veterinárias, Área de Saúde e Produção Animal Sustentável, Universidade Estadual do Centro-Oeste, UNICENTRO, Colaborador, Núcleo de Produção Animal, NUPRAN. Guarapuava, PR, Brasil. E-mail: bru. ze.venancio@gmail.com

2 Eng ${ }^{a}$ Agra ${ }^{a}$, Dr., Pesquisador do NUPRAN, Prof. Pós-Graduação, Cursos de Agronomia e Ciências Veterinárias, UNICENTRO, Guarapuava, PR, Brasil. E-mail: neumann.mikael@hotmail.com

3 Médico Veterinário, Dr. em Zootecnia, colaborador do NUPRAN. marlonrhs@hotmail.com

4 Discente de Graduação em Medicina Veterinária, UNICENTRO, Colaboradores do NUPRAN, Guarapuava, PR, Brasil. E-mail: giovannabpontarolo@hotmail.com, luisacosta23@outlook.com

5 Médica Veterinária, M.e em Ciências Veterinárias, UNICENTRO, Colaboradora do NUPRAN, Guarapuava, PR, Brasil. E-mail: lesleicaroline@hotmail.com

6 Eng $^{\circ}$ Agr $^{\circ}$, Dr., Colaborador, NUPRAN, Guarapuava, PR, Brasil. E-mail: leandro.alvarenga.s@hotmail.com

Eng $^{\circ}$ Agr ${ }^{\circ}$, M.e em Agronomia, Guarapuava, PR, Brasil. E-mail: jhonatansplietoff@hotmail.com

* Author for correpondence 
promising, than black oats, due to its productivity, combined with its better chemical composition and degradability.

Key words: Conserved forage. Degradability. Fungicide. Strobilurin.

\section{Resumo}

O objetivo do experimento foi avaliar a produtividade, o valor nutricional e a degradabilidade da forragem e da silagem de trigo (Triticum aestivum cv. BRS Umbu) e de aveia preta (Avena strigosa cv. Embrapa 139) precedidos de cortes sucessivos, colhidas em estádio de grão farináceo, submetidos ou não ao tratamento com fungicida piraclostrobina. A colheita das plantas foi realizada de forma manual com altura de $0,08 \mathrm{~m}$ da superfície do solo, em estádio de grão farináceo, após dois cortes em estádio vegetativo, realizou-se duas aplicações de piraclostrobina, $0,6 \mathrm{~L} \mathrm{ha}^{-1}$, antes do primeiro e do segundo corte. A piraclostobina diminuiu as perdas de matéria seca de $21,1 \%$ do sistema controle, para $7,7 \%$ para o sistema com piraclostrobina, diminuiu a fibsra em detergente neutro de $70,05 \%$ para $66,73 \%$, diminuiu a fibra em detergente ácido de $43,37 \%$ para $39,96 \%$, diminuiu a lignina de $14,37 \%$ para $10,13 \%$ e aumentou o valor relativo do alimento de $75,27 \%$ para $82,72 \%$, todos na forragem, que resultou em alterações na silagem, com a diminuição de fibra em detergente neutro de $64,00 \%$ para $58,46 \%$, fibra em detergente ácido de $38,76 \%$ para $35,87 \%$, lignina de $10,11 \%$ para $6,78 \%$ e incremento do valor relativo do alimento de 85,87 para 97,26 . Na avaliação das forrageiras o trigo apresentou as melhores produtividades, com $10.068 \mathrm{~kg} \mathrm{ha}^{-1}$, contra $8.238 \mathrm{~kg} \mathrm{ha}^{-1}$ da aveia preta, menor fibra em detergente neutro $(60,32 \%$ contra $76,46 \%)$, menor fibra em detergente ácido $(34,49 \%$ contra $48,84 \%)$ e maior valor relativo do alimento $(96,04$ contra 61,95$)$, dados estes da forragem, que foram refletidos na silagem resultante. Recomenda-se a utilização da piraclostrobina, pois a mesma diminui perdas durante a fermentação, altera a composição da fibra e melhora a degradabilidade do alimento. Dentre as forrageiras o trigo foi mais promissor, frente a aveia preta, devido a sua produtividade, aliada a sua melhor bromatologia e degradabilidade.

Palavras-chave: Degradabilidade. Estrobilurina. Forragem conservada, Fungicida.

\section{Introduction}

Preserved foods are of great importance to improve modern livestock systems, and preservation in the form of silage is the main source of feed supplied to ruminants in a feedlot system, in order to meet the nutritional requirements of the herd (NEUMANN et al., 2014).

All forages have the potential to be preserved as silage, however it is necessary to evaluate which forage has the best nutritional qualities, higher productivity and lower costs, desirable conditions and characteristics in animal production.

To achieve the favorable characteristics at the time of ensiling, a number of factors must be taken into account, such as the cutting point and the morphological composition of the plant (PAZIANI et al., 2013), which vary according to the materials chosen, the agricultural zoning, the technological level applied, knowing that these variations directly interfere not only with the productivity but also with the chemical characteristics of the resulting silage (GRALAK et al., 2014).

In regions where it is possible to grow winter grain crops, such as a large part of southern Brazil, these crops become one of the main alternatives for maximizing land use, minimizing degradation processes, increasing income and diversifying production of the property.

These cereals can be used for grain production, as green forage and also as preserved forage, in various forms (silages, haylage and hay). However, one of the main concerns in the cultivation of winter cereals is the high index of diseases, due to the characteristics of the winter of the Southern region, characterized as humid, with great amount of rainfall and cloudy days, making essential the 
control and prophylaxis of diseases, with the use of fungicides (REIS et al., 2001).

The use of fungicides has shown changes in productivity, not only by the reduction of losses related to diseases, but mainly to physiological changes of the plant, with the use of this practice (FERNANDES; PACININI, 1999).

Given the above, the goal of the experiment was to evaluate the productivity, physical composition and nutritional value of the forage and silage of two winter cereals preceded by successive cuts, harvested at the hard dough stage, subjected or not to the application of pyraclostrobin fungicide.

\section{Material and Methods}

The experiment was conducted at the Animal Production Center (NUPRAN) belonging to the Agrarian and Environmental Sciences sector of the Central Western State University (UNICENTRO), located in the municipality of Guarapuava, State of
Paraná, located in the subtropical zone of the state, at the geographical coordinates $25^{\circ} 23^{\prime} 02^{\prime \prime}$ South latitude and $51^{\circ} 29^{\prime} 43^{\prime \prime}$ 'West longitude and 1,026 m altitude.

The climate of the region according to the classification of Köppen is $\mathrm{Cfb}$ (subtropical mesothermal humid), with mild summer and moderate winter, with no defined dry season and with severe frosts. The soil of the experimental area was classified as typical haplohumox (POTT, 2007), and upon the implantation of the crops had the following chemical characteristics $(0-20 \mathrm{~cm}$ profile): $\mathrm{pH} 0.01 \mathrm{M} \mathrm{CaCl}_{2}$ : 4.7; $\mathrm{P}: 1.1 \mathrm{mg} \mathrm{dm}^{-3} ; \mathrm{K}^{+}$: $0.2 \mathrm{cmol} \mathrm{dm}^{-3}$; OM: $2.62 \mathrm{~g} \mathrm{dm}^{-3} ; \mathrm{Al}^{3+}: 0.0 \mathrm{cmolc} \mathrm{dm}^{-}$ 3; $\mathrm{H}^{+}+\mathrm{Al}^{3+}: 5.2 \mathrm{cmolc} \mathrm{dm}^{-3} ; \mathrm{Ca}^{2+}: 5.0 \mathrm{cmolc} \mathrm{dm}^{-}$ 3; $\mathrm{Mg}^{2+}: 5.0$ cmolc $\mathrm{dm}^{-3}$ and base saturation $(\mathrm{V} \%)$ : $67.3 \%$.

Figure 1 illustrates the average rainfall in $\mathrm{mm}$, as well as the daily maximum and minimum temperature in ${ }^{\circ} \mathrm{C}$ during the experimental period.

Figure 1. Rainfall averages $(\mathrm{mm})$, maximum and minimum temperature $\left({ }^{\circ} \mathrm{C}\right)$ occurred during the growing season of winter cereals.

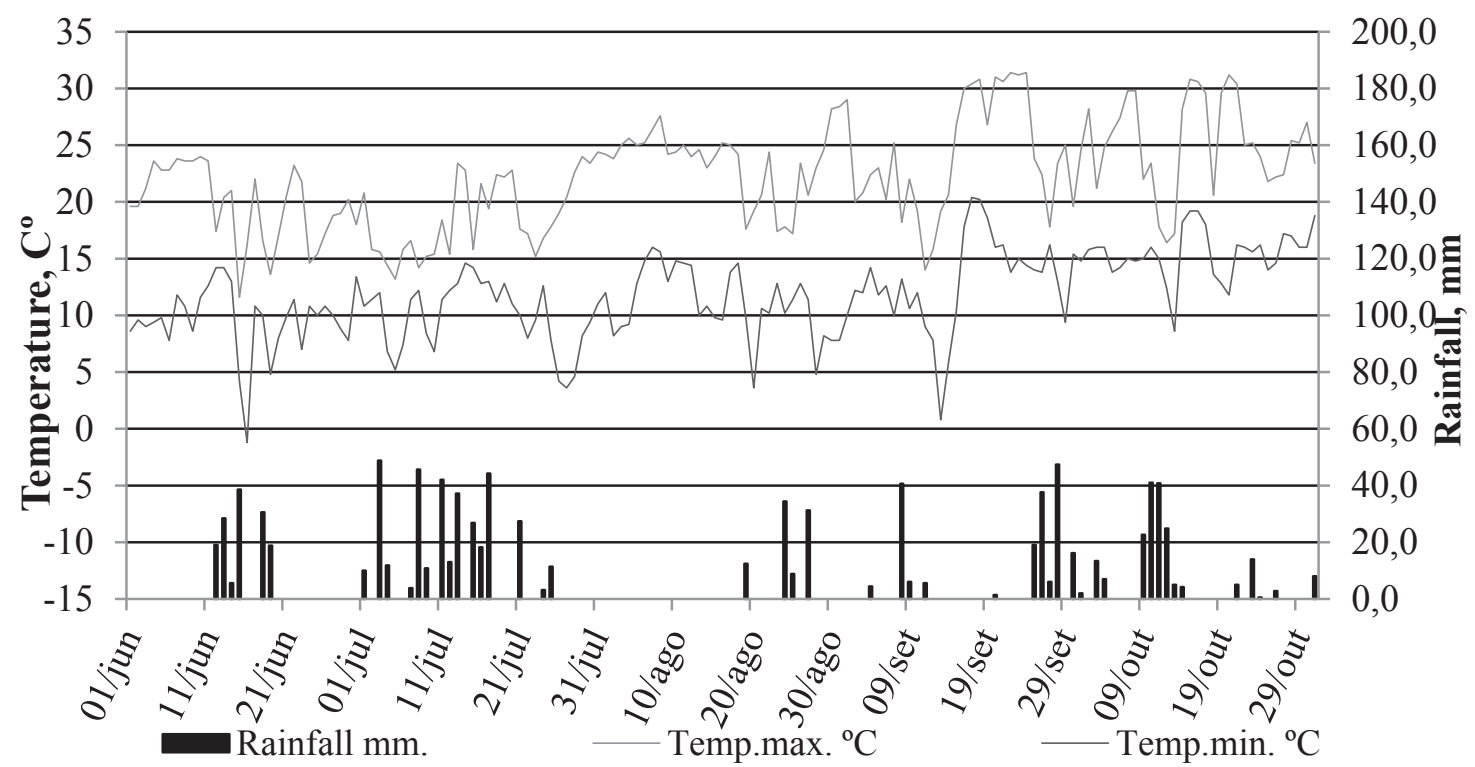

Source: SIMEPAR / UNICENTRO experimental station, Guarapuava, PR, 2015. 
Experimental material was wheat (Triticum aestivum cv. BRS Umbu) and black oats (Avena strigosa cv. Embrapa 139). The forage species were sown according to agricultural zoning for the region of Guarapuava, State of Paraná, under no-tillage system. The sowing was done in plots with an area of $5 \mathrm{~m}^{2}$, using Semina 1 sowing machine, with rows spaced 0.17 meters apart, average sowing depth of two centimeters and sowing density of $80 \mathrm{~kg} \mathrm{ha}^{-1}$.

Upon sowing, basal fertilization was performed with $250 \mathrm{~kg} \mathrm{ha}^{-1}$ of the fertilizer 08-20-20 ( $\mathrm{N}_{-} \mathrm{P}_{2} \mathrm{O}_{5}$ $\mathrm{K}_{2} \mathrm{O}$ ), respecting the recommendations of the soil fertility commission of Santa Catarina and Rio Grande do Sul (CQFS RS/SC, 2004). Nitrogen topdressing was performed at once, 42 days after sowing with $150 \mathrm{~kg} \mathrm{ha}^{-1}$ urea, either agricultural or livestock $(46 \% \mathrm{~N})$.

Invasive plants were chemically controlled with Glyphosate-based herbicide (Roundup $\mathrm{WG}^{\circledR}$ commercial product: $3.0 \mathrm{~kg} \mathrm{ha}^{-1}$ ) in the desiccation of the experimental area, 15 days before sowing, and in the management of the crop, 30 days after sowing with the application of the herbicide based on metsulfuron- methyl (Ally ${ }^{\circledR}$ commercial product: $\left.6.6 \mathrm{~g} \mathrm{ha}^{-1}\right)$.

The fungicide pyraclostrobin (commercial product Comet $^{\circledR}$, BASF, $250 \mathrm{~g} \mathrm{~L}^{-1}$ of the active principle) was applied at a dose of $0.6 \mathrm{~L} \mathrm{ha}^{-1}$ at two times during the vegetative phase, with the first application at the phenological stage V5 (elongation), and the second at 12 days after the first cut of each forage species. Spraying was performed with the aid of a motorized backpack sprayer, equipped with a bar containing four double flat fan nozzles, Twinjet TJ $60110.02,0.50 \mathrm{~m}$ spacing, with a volume of $200 \mathrm{~L} \mathrm{ha}^{-1}$ and spray pressure of $2.0 \mathrm{kgf}$ $\mathrm{cm}^{-2}$.

After the two harvests at the vegetative and full vegetative stages, plants were harvested at the hard dough grain stage. The material was weighed for determination of fresh biomass production $\left(\mathrm{kg} \mathrm{ha}^{-1}\right)$.
Homogeneous samples of each material were sent to the laboratory to determine the dry matter contents of the plant, using a forced air oven set at $55 \pm 5^{\circ} \mathrm{C}$, where the samples remained until obtaining constant weight. The relationship between the weight of the material harvested in the plot, corrected for area unit and the dry matter content of the plant, allowed to estimate the dry biomass production $\left(\mathrm{kg} \mathrm{ha}^{-1}\right)$.

The remainder of the plot was processed in a stationary forage chopper (Nogueira), homogenized, weighed $500 \mathrm{~g}$ of green material and then ensiled in vacuum bag experimental silos. After 260 days, the silos were opened and sent to the laboratory for determination of dry matter, using the aforementioned methodology.

The pre-dried samples of the original material were ground in a Wiley mill with a $1 \mathrm{~mm}$ sieve and analyzed for crude protein (CP) content by micro Kjeldahl method and mineral matter (MM) content by incineration at $550^{\circ} \mathrm{C}$ (for 4 hours), as well as neutral detergent fiber ( $\alpha$ NDF) and acid detergent fiber $(\alpha \mathrm{ADF})$, both adding alpha amylase and lignin (LIG), following the methodologies described by Silva and Queiroz (2009). From these values, hemicellulose (HEM) contents were calculated by difference between NDF and ADF, and cellulose (CEL) contents by difference between the ADF and the LIG. The total digestible nutrient (TDN\%) content was obtained via equation $[\mathrm{TDN} \%=87.84$ - (0.70 x ADF)], suggested by Bolsen (1996).

The dry matter rumen degradability was determined by the in situ technique using nylon bags measuring $12 \mathrm{~cm} \times 8 \mathrm{~cm}$ and with $55 \mu \mathrm{m}$ pores containing $5 \mathrm{~g}$ of each material, ground to $1 \mathrm{~mm}$, for later incubation in the rumen (NOCEK, 1988). The incubation times were $0,6,12,24,36$, and 48 hours, where the 0 -hour time represented the soluble fraction of the dry matter. For this, two steers with 48 months of age, average body weight of $650 \mathrm{~kg}$, and fitted with ruminal cannula were used. 
The experiment was a $2 \times 2$ factorial randomized complete block design, with two forage species of winter cereals (wheat and black oats) associated or not with fungicide, with four replications each treatment. The results were tested by analysis of variance and the means were compared by the F-test at $5 \%$ significance through the statistical software SAS (1993). Data on the rumen degradation rate of the dry matter were subjected to regression analysis (proc reg) of SAS.

\section{Results and Discussion}

Results of the analysis of variance indicated no significant interaction between forage species and fungicide application, at the time of ensiling and the resulting silage.

The use of pyraclostrobin, regardless of the evaluated forage species caused no alterations $(\mathrm{P}>0.05)$ in dry phytomass production of ensiled forage, however the dry matter losses were lower in silage treated with pyraclostrobin $(9.6 \%$ vs. $20.1 \%)$ in relation to the control test (Table 1).

Table 1. Dry matter production, dry matter losses (\%) and dry matter content (\%) of forage and silage resulting from wheat and black oats, preceded by successive cuts, submitted to application of pyraclostrobin.

\begin{tabular}{cccc}
\hline Pyraclostrobin & Forage & Fodder to be silage & Silage \\
\hline \multirow{3}{*}{ With } & & Phytomas, $\mathrm{kg} \mathrm{ha}^{-1}$ & Losses, $\%$ \\
& Wheat & 8.002 & 12,5 \\
& Black Oats & 6.713 & 6,7 \\
& Average & $7.357 \mathrm{~A}$ & $9,6 \mathrm{~A}$ \\
& Wheat & 8.106 & 16,9 \\
Without & Black Oats & 6.469 & 23,4 \\
& Average & $7.288 \mathrm{~A}$ & $20,1 \mathrm{~B}$ \\
\hline & Wheat & $8.054 \mathrm{a}$ & $14,7 \mathrm{a}$ \\
& Black Oats & $6.591 \mathrm{~b}$ & $15,0 \mathrm{a}$ \\
\hline \multirow{3}{*}{ With } & & & \\
& Wheat & 39,05 & 35,66 \\
& Black Oats & 28,65 & 27,79 \\
& Average & $33,85 \mathrm{~B}$ & $31,73 \mathrm{~B}$ \\
& Wheat & 44,76 & 36,51 \\
& Black Oats & 45,54 & 40,45 \\
& Average & $45,15 \mathrm{~A}$ & $38,48 \mathrm{~A}$ \\
\hline
\end{tabular}

Averages, followed by upper case letters, in the column, in the comparison between treatments with and without fungicide, differ by the $\mathrm{F}$ test at $5 \%$.

Averages, followed by lower case letters, in the column, in the comparison between forage species, differ by the $\mathrm{F}$ test at $5 \%$.

The use of pyraclostrobin may increase the productivity of wheat grains by $1,080 \mathrm{~kg} \mathrm{ha}^{-1}$ (TROJAN et al., 2010), and/or 2,837 $\mathrm{kg} \mathrm{ha}^{-1}$ (KUHNEM JUNIOR et al., 2009). It is also possible to increase total phytomass by $25.91 \mathrm{~g}$ soybean plant $^{-1}$ (SOARES et al., 2011). These productivity increases did not occur in the present experiment probably due to the production objective, with total plant harvest. 
Losses during silage fermentation process are unavoidable, the methodology used to verify these losses was through the dry matter recovery index proposed by Jobim et al. (2007). The lowest losses were found In the treatment with pyraclostrobin, according to Haer et al. (2015), which may be related to the lower fungal load and the higher concentration of sugar in plants treated with pyraclostrobin, which provide a faster and more efficient fermentation, since the bacteria transform these sugars into acetic acid and lactic acid, mainly (NEUMANN et al., 2014).

In general, considering only the effect of evaluated forage species, regardless of the application of pyraclostrobin, black oats obtained the lowest $(\mathrm{P}<0.05)$ dry phytomass production with $6,591 \mathrm{~kg} \mathrm{ha}^{-1}$ in relation to wheat with 8,054 $\mathrm{kg} \mathrm{ha}^{-1}$. Regarding dry matter losses, there was no difference $(\mathrm{P}>0.05)$ between forage species, with a mean value of $14.9 \%$. Leão et al. (2017) analyzed different winter cereals for silage production and reported the lowest losses of dry matter for barley with $8.4 \%$, followed by wheat with $17.2 \%$, white oats with $17.4 \%$ and black oats with $22.0 \%$, showing differences in losses between species.

With respect to the average dry matter content of ensiled forage and resulting silage, it was observed that the treatment with pyraclostrobin showed lower values $(\mathrm{P}<0.05)(33.9 \%$ and $31.7 \%$ vs. 45.5 and $40.4 \%$, respectively) compared to the control.

Although the harvest was carried out at the same vegetative stage, the treatments showed different dry matter contents, and the treatment with pyraclostrobin presented within the ideal dry matter values for the ensiling process, which vary from $32 \%$ to $40 \%$ dry matter (NEUMANN et al., 2014).

In the comparison between forage species, the forage dry matter content was higher $(\mathrm{P}<0.05)$ in wheat $(41.9 \%$ vs. $37.1 \%)$ compared to the values found in black oats. In turn, dry matter contents of the resulting silage were similar $(\mathrm{P}>0.05)$ between wheat (36.1\%) and black oats (34.1\%) (Table 1).
It can be observed in Table 2 that the use of pyraclostrobin, independently of the evaluated forage species, promoted an increase $(\mathrm{P}<0.05)$ in mineral matter content of the ensiled forage $(4.2 \%$ vs. $3.2 \%$ ) and the silage ( $4.0 \%$ vs. $3.6 \%$ ) compared to the control; while for the crude protein content, there were no changes $(\mathrm{P}>0.05)$ in both forage at the time of ensiling and in the resulting silages.

Ingeneral, considering only the effect of evaluated forage species, regardless of the application of pyraclostrobin, it was verified that black oats had higher $(\mathrm{P}<0.05)$ mineral matter contents both in forage at the time of ensiling ( $4.5 \%$ vs. $3.2 \%)$ and in the resulting silage ( $4.3 \%$ vs. $3.3 \%)$, compared to wheat; while for crude protein content, the behavior was opposite, with lower values $(\mathrm{P}<0.05)$ in black oats $(8.4 \%$ vs. $9.4 \%)$ compared to wheat at the time of ensiling and similar values $(\mathrm{P}>0.05)$ in the resulting silage ( $8.3 \%$ vs. $8.6 \%$ ) (Table 2$)$.

Leão et al. (2017) stated that black oat silage presents higher values of mineral matter compared to wheat, which increases the buffering capacity and can hinder fermentation and $\mathrm{pH}$ lowering, making silage susceptible to deleterious effects caused by microorganisms.

The use of pyraclostrobin, regardless of the evaluated forage species, resulted in significant reductions $(\mathrm{P}<0.05)$ and very important alterations in the chemical composition of the plants, both in forage at the time of ensiling and in the resulting silage, where on average the neutral detergent fiber $(66.7 \%$ and $58.5 \%$ vs. $70.0 \%$ and $64.0 \%$, respectively) and acid detergent fiber $(40.0 \%$ and $35.9 \%$ vs. $43.4 \%$ and $38.8 \%$, respectively) contents were lower than the control. As for hemicellulose contents, these were similar $(\mathrm{P}>0.05)$ with or without the use of pyraclostrobin in forage at the time of ensiling, but in the evaluation of the resulting silage, the lowest hemicellulose content was found in the treatment using pyraclostrobin $(22.6 \% \mathrm{vs}$. 25.24\%) compared to the control (Table 3). 
Table 2. Mineral matter (\%) and crude protein (\%) of forage and silage resulting from wheat and black oats, preceded by successive cuts, submitted to application of pyraclostrobin.

\begin{tabular}{cccc}
\hline Pyraclostrobin & Forage & Fodder to be silage & Silage \\
\hline \multirow{3}{*}{ With } & Wheat & Mineral Matter, \% of DM & 3,23 \\
& Black Oats & 3,28 & 4,68 \\
& Average & 5,17 & $3,96 \mathrm{~A}$ \\
\multirow{3}{*}{ Without } & Wheat & $4,22 \mathrm{~A}$ & 3,40 \\
& Black Oats & 3,17 & 3,91 \\
& Average & 3,86 & $3,65 \mathrm{~A}$ \\
\hline \multirow{3}{*}{ With } & Trigo & $3,51 \mathrm{~B}$ & $3,32 \mathrm{~b}$ \\
& Aveia preta & $3,22 \mathrm{~b}$ & $4,29 \mathrm{a}$ \\
\hline \multirow{3}{*}{ Without } & Wheat & $4,51 \mathrm{a}$ & 8,48 \\
& Black Oats & 9,36 & 8,75 \\
& Average & 7,85 & $8,61 \mathrm{~A}$ \\
& Wheat & $8,61 \mathrm{~A}$ & 8,65 \\
& Black Oats & 9,50 & 7,86 \\
& Average & 8,90 & $8,26^{\mathrm{a}}$ \\
& Wheat & $9,20 \mathrm{~A}$ & $8,57 \mathrm{a}$ \\
& Black Oats & $9,43 \mathrm{a}$ & $8,30 \mathrm{a}$ \\
\hline
\end{tabular}

Averages, followed by upper case letters, in the column, in the comparison between treatments with and without fungicide, differ by the F test at $5 \%$.

Averages, followed by lower case letters, in the column, in the comparison between forage species, differ by the $\mathrm{F}$ test at $5 \%$.

According to Mendes et al. (2008), the application of strobilurin leads to the increase in neutral detergent fiber compared to the control, due to the higher height of the treated plant, however the data do not corroborate the data of the present study, in which the neutral detergent fiber values were lower with the application of pyraclostrobin.

For acid detergent fiber values, Mendes et al. (2018) found no differences between the treatment with strobilurin and the control. With the application of pyraclostrobin at the vegetative stage and the forage harvested at the hard dough stage, it was possible to find a reduction in acid detergent fiber, possibly due to the lower concentration of structural components due to the green effect of pyraclostrobin (VENANCIO et al., 2004).

For the hemicellulose contents, there were no differences as for the application or not of strobilurin and as for the application stage (MENDES et al., 2018), the same occurred in the present study where there were no alterations $(\mathrm{P}>0.05)$ in the contents of hemicellulose. 
Table 3. Neutral detergent fiber (\%), hemicellulose (\%) and acid detergent fiber of forage and silage resulting from wheat and black oats, preceded by successive cuts, submitted to application of pyraclostrobin.

\begin{tabular}{|c|c|c|c|}
\hline Pyraclostrobin & Forage & Fodder to be silage & Silage \\
\hline \multicolumn{4}{|c|}{ Neutral detergent fiber, $\%$ of DM } \\
\hline \multirow{4}{*}{ With } & Wheat & 58,45 & 56,49 \\
\hline & Black Oats & 75,02 & 60,44 \\
\hline & Average & $66,73 \mathrm{~B}$ & $58,46 \mathrm{~B}$ \\
\hline & Wheat & 62,20 & 59,83 \\
\hline \multirow[t]{6}{*}{ Without } & Black Oats & 77,90 & 68,17 \\
\hline & Average & $70,05 \mathrm{~A}$ & $64,00 \mathrm{~A}$ \\
\hline & Wheat & $60,32 \mathrm{~b}$ & $58,16 \mathrm{~b}$ \\
\hline & Black Oats & $76,46 \mathrm{a}$ & $64,30 \mathrm{a}$ \\
\hline & & emicellulose, $\%$ of $\mathrm{D}$ & \\
\hline & Wheat & 25,04 & 21,81 \\
\hline \multirow[t]{3}{*}{ With } & Black Oats & 28,51 & 23,38 \\
\hline & Average & $26,77 \mathrm{~A}$ & $22,59 \mathrm{~B}$ \\
\hline & Wheat & 26,63 & 22,80 \\
\hline \multirow[t]{6}{*}{ Without } & Black Oats & 26,73 & 27,69 \\
\hline & Average & $26,68 \mathrm{~A}$ & $25,24 \mathrm{~A}$ \\
\hline & Wheat & $25,83 \mathrm{a}$ & $22,30 \mathrm{~b}$ \\
\hline & Black Oats & $27,62 \mathrm{a}$ & $25,54 \mathrm{a}$ \\
\hline & & detergent fiber, $\%$ of & \\
\hline & Wheat & 33,41 & 34,68 \\
\hline \multirow[t]{3}{*}{ With } & Black Oats & 46,50 & 37,06 \\
\hline & Average & $39,96 \mathrm{~B}$ & $35,87 \mathrm{~B}$ \\
\hline & Wheat & 35,57 & 37,03 \\
\hline \multirow[t]{4}{*}{ Without } & Black Oats & 51,17 & 40,48 \\
\hline & Average & $43,37 \mathrm{~A}$ & $38,76 \mathrm{~A}$ \\
\hline & Wheat & $34,49 \mathrm{~b}$ & $35,65 \mathrm{~b}$ \\
\hline & Black Oats & $48,84 \mathrm{a}$ & $38,77 \mathrm{a}$ \\
\hline
\end{tabular}

Averages, followed by upper case letters, in the column, in the comparison between treatments with and without fungicide, differ by the $\mathrm{F}$ test at $5 \%$.

Averages, followed by lower case letters, in the column, in the comparison between forage species, differ by the $\mathrm{F}$ test at $5 \%$.

In comparing forage species (Table 3), regardless of whether or not piraclostrobin was applied, it was found that black oats had higher $(\mathrm{P}<0.05)$ neutral detergent fiber $(76.5 \%$ and $64.3 \%$ vs. $60.3 \%$ and $58.2 \%$, respectively) and acid detergent fiber ( $48.8 \%$ and $38.8 \%$ vs. 34.55 and $35.9 \%$, respectively) contents, both in forage at the time of ensiling, as in the resulting silage, relative to wheat.
Black oat tends to have higher content of neutral detergent fiber, probably because it presents lower grain yields, compared to the other species studied (MEINERZ et al., 2012), which reduces the dilution of the fiber, which can be employed for acid detergent fiber concentrations. In addition to this, black oats has higher height (FONTANELI et al., 2007), requiring higher concentrations of structural carbohydrates to avoid lodging. 
It can be observed in Table 4 that the use of pyraclostrobin, independently of the evaluated forage species, determined significant reductions ( $\mathrm{P}$ $<0.05$ ), both in forage at the time of ensiling and in the resulting silage, as for lignin contents $(10.1 \%$ and $6.8 \%$ vs. $14.4 \%$ and $10.11 \%$, respectively) and a significant increase $(\mathrm{P}<0.05)$ in the relative value of the food $(82.7 \%$ and $97.3 \%$ vs. $75.3 \%$ and $85.9 \%$, respectively) compared to the control. The cellulose contents remained stable $(\mathrm{P}>0.05)$ both in forage at the time of ensiling and in the resulting silage with or without pyraclostrobin.

In the comparison of forage species, regardless of the application or not of pyraclostrobin, it was verified that both forage at the time of ensiling and in the resulting silage, black oats had higher $(\mathrm{P}<0.05)$ cellulose contents ( $36.3 \%$ and $28.6 \%$ vs. $22.5 \%$ and $24.4 \%$, respectively) and lower $(\mathrm{P}<0.05)$ relative value of the food (61.9 and 85.4 vs. 96.0 and $97.7 \%$, respectively) in relation to wheat. Lignin contents were similar $(\mathrm{P}>0.05)$ in both forage species, both in forage at the time of ensiling and in the resulting silage.

It is possible to observed higher values of intercept (Table 5) regarding the ruminal disappearance rate of dry matter, which can be referred to as soluble nutrients, for the treatment with application of pyraclostrobin, in ensiled forage, with a mean of $27.76 \%$ vs. $22.84 \%$ of the control, showing that the use of pyraclostrobin increases rumen degradability. In the forage average, the ruminal disappearance rate of dry matter was better for the treatment with application of pyraclostrobin, with 0.64 vs. $0.52 \%$ per hour of incubation

The intercept point for ruminal degradability of dry matter of ensiled forage from different species showed that wheat presented higher contents of soluble nutrients compared to black oats, regardless of whether or not pyraclostrobin was applied. In the evaluation between the forages, it is possible to verify that the black oats had less degradation per hour, resulting in the end with a lower degradability.

For the resulting silage, the same forage line is used, where the application of pyraclostrobin to soluble nutrient results is higher (27.76 vs. $26.13 \%$ ) compared to the control trial. The dry matter rumen degradation rate was also higher for the treatment with pyraclostrobin, which reached $0.59 \%$ per hour vs. $0.44 \%$ of the control, resulting in higher degradability values for the pyraclostrobin-treated material.

According to Figure 2 and Table 5, it is possible to verify that, at the time of ensiling, as well as in the resulting silage, there was difference $(\mathrm{P}<0.05)$ in the rumen degradation rate under individual effects to the application or not of pyraclostrobin with individual effects on the comparison of forages. 
Figure 2. Rate of degradability dry matter degradation rate of forage and silage resulting from wheat and black oats, preceded by successive cuts, submitted to application of pyraclostrobin.
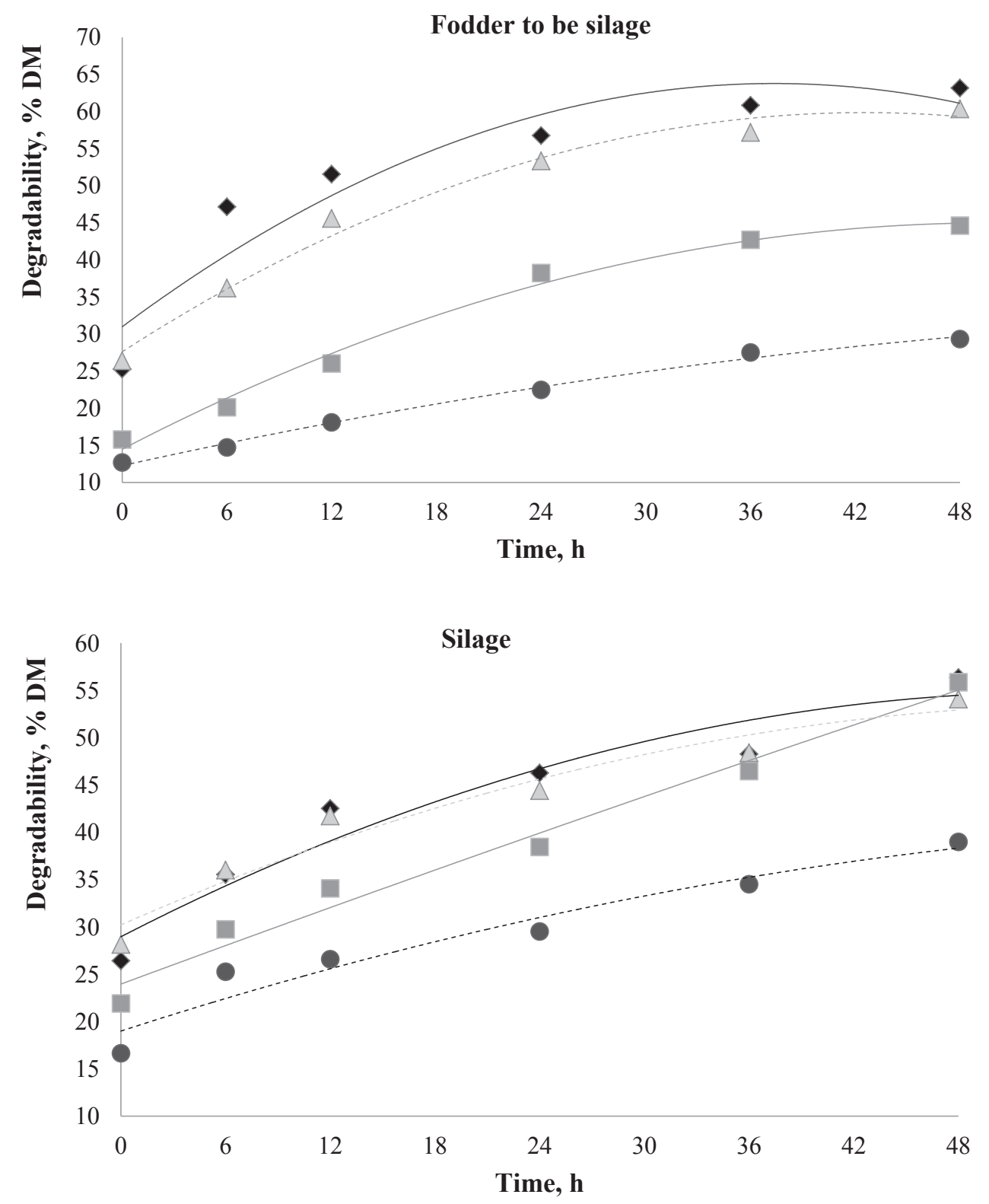

- wheat, with pyraclostrobin $\quad$ black oats, with pyraclostrobin
$\Delta$ wheat, without pyraclostrobin $\quad$ black oats, without pyraclostrobin

The changes in the chemical characteristics of forage at the time of ensiling and in resulting silage, mainly the lower content of lignin, led to a better in situ degradability of the materials treated with pyraclostrobin, and it can be inferred that there are higher contents of total digestible nutrients, such as the data of Haerr et al. (2015). Despite the higher content of total digestible nutrients, the aforementioned authors found no differences in degradability for corn silage treated with pyraclostrobin. 
Table 4. Cellulose (\%), lignin (\%) and relative vallue of food (index) of forage and silage resulting from wheat and black oats, preceded by successive cuts, submitted to application of pyraclostrobin.

\begin{tabular}{|c|c|c|c|}
\hline Pyraclostrobin & Forage & Fodder to be silage & Silage \\
\hline & & \multicolumn{2}{|c|}{ Cellulose, $\%$ of DM } \\
\hline & Wheat & 25,50 & 27,96 \\
\hline \multirow[t]{3}{*}{ With } & Black Oats & 34,15 & 30,21 \\
\hline & Average & $29,82 \mathrm{~A}$ & $29,08 \mathrm{~A}$ \\
\hline & Wheat & 19,45 & 20,88 \\
\hline \multirow[t]{6}{*}{ Without } & Black Oats & 38,54 & 26,92 \\
\hline & Average & $29,00 \mathrm{~A}$ & $23,90 \mathrm{~A}$ \\
\hline & Wheat & $22,48 \mathrm{~b}$ & $24,42 \mathrm{a}$ \\
\hline & Black Oats & $36,35 \mathrm{a}$ & $28,56 \mathrm{a}$ \\
\hline & & \multicolumn{2}{|c|}{ Lignin, $\%$ of DM } \\
\hline & Wheat & 7,91 & 6,72 \\
\hline \multirow[t]{3}{*}{ With } & Black Oats & 12,36 & 6,85 \\
\hline & Average & $10,13 \mathrm{~B}$ & $6,78 \mathrm{~B}$ \\
\hline & Wheat & 16,11 & 9,65 \\
\hline \multirow[t]{6}{*}{ Without } & Black Oats & 12,63 & 10,56 \\
\hline & Average & $14,37 \mathrm{~A}$ & $10,11 \mathrm{~A}$ \\
\hline & Wheat & $12,01 \mathrm{a}$ & $8,19 \mathrm{a}$ \\
\hline & Black Oats & $12,49 \mathrm{a}$ & $8,71 \mathrm{a}$ \\
\hline & & \multicolumn{2}{|c|}{ Relative vallue of food, index } \\
\hline & Wheat & 100,12 & 102,00 \\
\hline \multirow[t]{3}{*}{ With } & Black Oats & 65,32 & 92,52 \\
\hline & Average & $82,72 \mathrm{~A}$ & $97,26 \mathrm{~A}$ \\
\hline & Wheat & 91,96 & 93,45 \\
\hline \multirow[t]{4}{*}{ Without } & Black Oats & 58,58 & 78,30 \\
\hline & Average & $75,27 \mathrm{~B}$ & $85,87 \mathrm{~B}$ \\
\hline & Wheat & $96,04 \mathrm{a}$ & $97,72 \mathrm{a}$ \\
\hline & Black Oats & $61,95 \mathrm{~b}$ & $85,41 \mathrm{~b}$ \\
\hline
\end{tabular}

Averages, followed by upper case letters, in the column, in the comparison between treatments with and without fungicide, differ by the $\mathrm{F}$ test at $5 \%$.

Averages, followed by lower case letters, in the column, in the comparison between forage species, differ by the $\mathrm{F}$ test at $5 \%$. 
Table 5. Regression equation values for rumen dry matter degradation rate of forage and silage resulting from wheat and black oats, preceded by successive cuts, submitted to application of pyraclostrobin.

\begin{tabular}{cccccc}
\hline Pyraclostrobin & Forage & $\mathrm{b} 0(\%)$ & $\mathrm{b} 1 \mathrm{X}\left(\% \mathrm{~h}^{-1}\right)$ & $\mathrm{R}^{2}$ & $\mathrm{CV}(\%)$ \\
\hline \multirow{4}{*}{ With } & Wheat & 37,4544 & 0,6353 & 0,7074 & 14,18 \\
& Black Oats & 17,8474 & 0,6388 & 0,9184 & 10,74 \\
& Average & 27,7627 & 0,6370 & 0,4819 & 27,72 \\
Without & Wheat & 32,5176 & 0,6670 & 0,8328 & 11,32 \\
& Black Oats & 13,1686 & 0,3632 & 0,9174 & 9,24 \\
& Average & 22,8431 & 0,5151 & 0,2885 & 41,44 \\
\hline \multirow{5}{*}{ With } & & Silage & \\
& Wheat & 31,3662 & 0,5336 & 0,8013 & 11,00 \\
& Black Oats & 24,1646 & 0,6477 & 0,9383 & 7,76 \\
\multirow{2}{*}{ Without } & Average & 27,7654 & 0,5906 & 0,8277 & 11,57 \\
& Wheat & 32,1538 & 0,4756 & 0,8946 & 6,83 \\
& Black Oats & 20,1139 & 0,4039 & 0,8771 & 9,32 \\
& Average & 26,1338 & 0,4398 & 0,5084 & 21,08 \\
\hline
\end{tabular}

b0: intercept; b1 X: rate of degradability per hour of incubation; CV: coefficient of variation.

\section{Conclusion}

The use of pyraclostrobin in wheat and black oats for silage production decreased losses during fermentation and storage and led to changes in the fiber portion of the plant, resulting in better ruminal degradability rates.

Wheat was more promising for silage production than black oats, because it combined higher production with better chemical characteristics and rumen degradability of dry matter.

\section{References}

BOLSEN, K. K.; ASHBELL, G.; WEINBERG, Z. G. Silage fermentation and silage additives-Review. AsianAustralasian Journal of Animal Sciences, v. 9, n. 5, p. 483-494, 1996. DOI: 10.5713/ajas.1996.483

COMISSÃO DE QUÍMICA E FERTILIDADE DO SOLO - CQFS RS/SC. Manual de adubação e de calagem para os Estados do Rio Grande do Sul e de Santa Catarina. 10. ed. Sociedade Brasileira de Ciência do Solo, 2004. 400 p.
FERNANDES, J. M. C.; PICININI, E. C. Ganhe controlando as doenças do trigo na hora certa, Cultivar, n. 4, p. 18-22. 1999.

FONTANELI, R. S.; FONTANELI, R. S.; SANTOS, H. P.; ACOSTA, A.; CARVALHO, O. S. Cereais de inverno de duplo propósito na integração lavoura-pecuária: aveia, cevada, centeio, trigo, triticale. Embrapa TrigoDocumentos, INFOTECA-E, 2007. 24 p.

GRALAK, E.; FARIA, M. A.; POSSATO JÚNIOR, O.; ROSSI, E. S.; SILVA, C. A.; RIZZARDI, D. A.; MENDES, M. C.; NEUMANN, M. Capacidade combinatória de híbridos de milho para caracteres agronômicos e bromatológicos da silagem. Revista Brasileira de Milho e Sorgo, v. 13, n. 2, p. 187-200. 2014. DOI: $10.18512 / 1980-6477 /$ rbms.v13n2p187-200

HAERR, K. J.; LOPES, N. M.; PEREIRA, M. N.; FELLOWS, G. M.; CARDOSO, F. C. Corn silage from corn treated with foliar fungicide and performance of Holstein cows. Journal of Dairy Science, v. 98, n. 12, p. 8962-8972, 2015. DOI: $10.3168 /$ jds.2015-9887

JOBIM, C. C.; NUSSIO, L. G.; REIS, R. A.; SCHIMIDT, P. Avanços metodológicos na avaliação da qualidade da forragem conservada. Revista Brasileira de Zootecnia, v. 36, p. 101-119, 2007. Edição Especial. DOI: 10.1590/ S1516-35892007001000013 
KUHNEM JUNIOR, P. R.; CASA, R. T.; RIZZI, F. P.; MOREIRA, E. N.; BOGO, A. Desempenho de fungicidas no controle de doenças foliares em trigo. Revista de Ciências Agroveterinárias, v. 8, n. 1, p. 25-42, 2009.

LEÃO, G. F. M.; JOBIM, C. C.; NEUMANN, M.; HORST, E. H.; SANTOS, S. K. D.; VENANCIO, B. J.; SANTOS, L.C. Nutritional composition and aerobic stability of winter cereal silage at different storage times. Acta Scientiarum. Animal Sciences, v. 39, n. 2, p. 131136, 2017. DOI: 10.4025/actascianimsci.v.39i2.34270

MEINERZ, G. R.; OLIVO, C. J.; FONTANELI, R. S.; AGNOLIN, C.A.; HORST, T.; BEM, C. M. Produtividade de cereais de inverno de duplo propósito na depressão central do Rio Grande do Sul. Revista Brasileira de Zootecnia, v. 41, n. 4, p. 873-882, 2012. DOI: 10.1590/ S1516-35982012000400007

MENDES, M. C.; MENDES, E. D.; NEUMANN, M.; STADLER JUNIOR, A.; NEIVERTH, J. Características bromatológicas de trigo duplo propósito associado à aplicação foliar de fungicida. Applied Research \& Agrotechnology, v. 11, n. 1, p. 43-50, 2018. DOI: 10.5935/PAeT.V11.N1.05

NEUMANN, M.; FIGUEIRA, D. N.; BUMBIERIS JR., V. H.; UENO, R. K.; LEÃO, G. F. M. Ensilagem: Estratégias visando maior produção de leite. In: SIMPÓSIO BRASILEIRO DE RUMINANTES LEITEIROS UDILEITE, 1., Uberlândia, 2014. Anais... Uberlândia: Universidade Federal de Uberlândia, 2014. p. $130-166$.

NOCEK, J. E. In situ and other methods to estimate ruminal protein and energy digestibility. A review. Journal Dairy Science, v. 71, n. 8, p. 2051-206, 1988. DOI: $10.3168 /$ jds.S0022-0302(88)79781-7

PAZIANI, S. F.; DUARTE, A. P.; NUSSIO, L. G.; GALLO, P. B.; MATEUS, G. P.; FREITAS, R. S.;
FINOTO, E. L.; MARTINS, A. L. M.; CABEZAS, W. A. R. L.; STRADA, W. L. Avaliação de cultivares de milho para produção de silagem no estado de São Paulo na safra 2011/12. Nucleus, v. 10, n. 3, 2013. Edição Especial. DOI: $10.3738 /$ nucleus.v0i0.918

POTT, C. A.; MÜller, M. M. L.; BERTELli, P. B. Adubação verde como alternativa agroecológica para recuperação da fertilidade do solo. Revista Ambiência, v. 3, n. 2, p. 51-63, 2007.

REIS, E. M.; CASA, R. T.; MEDEIROS, S. A. Diagnose, patometria e controle de doenças de cereais de inverno. Londrina: Criação e Editoração ES Comunicações S/C Ltda. Impressão MC Gráfica Ltda., 2001. 94 p.

STATISTICAL ANALYSIS SYSTEM INSTITUTE SAS. SAS/STAT user's guide: statistics. 4. ed. Version 6. Cary, North Caroline, v. 2, p. 943, 1993.

SILVA, D. J.; QUEIROZ, A. C. Análise de alimentos: métodos químicos e biológicos. 3. ed. Viçosa: Universidade Federal de Viçosa, 2009. 235 p.

SOARES, L. H.; FAGAN, E. B.; CASAROLI, D.; ANDRADE, D. M.; SOARES, A. L.; MARTINS, K. V.; ROCHA, F. J. Aplicação de diferentes estrobilurinas na cultura da soja. Revista da Faculdade de Zootecnia, Veterinária e Agronomia, v. 18, n. 1, p. 78-97, 2011.

TROJAN, D. G. Avaliação do efeito de piraclostrobina aplicada ao final do perfilhamento sobre a produtividade da cultura do trigo (Triticum aestivum L.). 2009. (Dissertação de Mestrado em Agronomia) - Universidade Estadual de Ponta Grossa, Ponta Grossa.

VENANCIO, W. S.; RODRIGUES, M. A. T.; BEGLIOMINI, E.; SOUZA, N. L. Efeitos fisiológicos de fungicidas sobre plantas. 1. Efeitos fisiológicos do fungicida piraclostrobina. Revisão Anual de Patologia de Plantas, Passo Fundo, v. 12, 2004. p. 317-341. 
